\title{
A esperança como revide ou o maravilhoso mundo da literatura de Abdulai Sila
}

\author{
Hope as retaliation or the wondrous world of \\ Abdulai Sila's literature
}

\section{Sebastião MarQues Cardoso *}

Resumo: Neste artigo, trataremos do conjunto da literatura de Abdulai Sila [1958-] e, em especial, de Dois tiros e uma gargalhada (2013), última publicação do escritor. Investigaremos como dois sistemas culturais de representação - o africano e o ocidental - apreendem a questão da história e de como esses sistemas interagem na contemporaneidade. Para tanto, iremos discutir a figuração da identidade dos principais personagens de Sila, verificar neles redes e relações de alteridade, intersecções espaçotemporais e formas de identificação com a tradição. Suspeitamos, enfim, que há, nesse autor, um entendimento da história que recupera a magia cultural africana em contraposição à fatalidade da concepção de história posta pelo ocidente.

Palavras-chave: Teoria literária, literaturas africanas de língua portuguesa, estudos póscoloniais, Abdulai Sila.

Abstract: This paper discusses the work of Abdulai Sila [1958-], and, more especifically, Dois tiros e uma gargalhada (2013), last publication by the author. We are going to investigate how two cultural systems of representation - the african and the western aprehend history and how these systems interact in contemporary times. To this end, we will discuss the identities' figuration of the main characters, as well as verify networks and alterity relations, spatiotemporal intersections and forms of identification with tradition. We suspect, then, that there is in the work of this author an understanding of history that recovers the african cultural magic in contrast to the inevitability of the conception of history posed by the west.

Keywords: Literary theory, african literatures in Portuguese, postcolonial studies, Abdulai Sila.

\footnotetext{
Professor Adjunto em Teoria da Literatura do Departamento de Letras Estrangeiras, pesquisador permanente do Programa de Pós-Graduação em Letras, mestrado e doutorado, da Universidade do Estado do Rio Grande do Norte (UERN, Brasil).
} 


\section{Considerações iniciais e problematização}

Estamos todos nós estreando um combate interno para domesticar os nossos antigos fantasmas. Mia Couto - À porta da modernidade, há sete sapatos sujos que necessitamos descalçar (2014).

...apesar de todo o progresso feito nos últimos anos, parece que ainda continuam a pairar entre nós alguns fantasmas do passado.

Abdulai Sila - Dois tiros e uma gargalhada (2013).

esde a primeira publicação - Eterna paixão (1994) - Abdulai Sila oferece ao público uma literatura cujo horizonte imaginado contrasta a fervilhante percepção do mundo interior dos indivíduos com a narrativa obsedante e imposta de um mundo alheio, ou, dito de maneira mais clara, a narrativa de Sila contempla o ambíguo, fraturado e agonístico espaço da subjetividade do mundo pós-colonial africano (cf. Cardoso, 2014). Esse dialogismo, ou seja, essa interface entre "mundos" é, talvez, a característica mais importante e recorrente na literatura do escritor nascido em Guiné-Bissau. Em outras palavras, a narrativa dada do mundo histórico-empírico aparece na ficção de Sila com suspeição e, também, como possível ponto de viragem para uma nova narrativa da realização do mundo.

A contradição nisso tudo reside na constatação, entretanto, de que o mundo novo imaginado é "apenas-literatura" ou, de maneira mais pragmática, uma sugestão artística de mudança de rota à narrativa do mundo real. Sila, com sua literatura, expõe as fraturas da pós-colonização em África, na mesma medida em que, incansavelmente, indica um novo projeto para a realização da vida na História. Sila acena para o fim da intransitividade entre literatura e realidade. Como Walter Benjamin (1994) pensou o conceito de História, através da alegoria 
do Angelus Novus - quadro de Paul Klee - o discurso literário de Sila faz apelo à consciência do vivido, tentando "despertar os mortos e juntar os destroços" do tempo para que haja um entendimento do processo histórico na mesma medida em que ele acontece. Mas a História, implacável, segue o seu curso. Sila mostra, então, um espectro da História, a sua contingência, a sua imprevisibilidade ou esperança como forma de revide.

O romance A última tragédia (1995), de Abdulai Sila, embora trate do período da colonização, foi escrito pelo autor no tempo da pós-colonialidade. Nessa obra, o autor expõe as contrariedades do período colonial na então Guiné Portuguesa, sob a perspectiva dos próprios bissauguineenses. O mundo apresentado no romance é o mundo marcado pela opressão dos colonizadores sobre os colonizados, ou seja, dos brancos estrangeiros sobre os negros autóctones. No romance não há um desfecho propriamente dito, mas há sinais de que a tensão entre brancos e negros será cada vez mais aguda e culminará, mais adiante, num confronto violento em larga escala, onde os locais, os bissauguineenses, exigem a saída imediata dos colonizadores de seu território. Essa narrativa, implícita no romance, se confirma com o desdobrar da História. Através da luta armada, Guiné-Bissau conquista sua independência política em 1973.

Paralelamente ao decurso da História, que leva à luta armada e, em seguida, à libertação do país, há em A última tragédia uma outra história, "passada" como denomina o narrador, que não foi contada. Para além da história de vidas particulares que foram arruinadas pela colonização (vejam o caso de Ndani e do Professor, por exemplo), Sila mostra, através do testamento de um importante Régulo, que houve um plano anterior para expulsar os colonos sem necessitar, entretanto, derramar sequer uma gota de sangue. É nesse ponto que acreditamos estar a mais singular contribuição de Sila. O autor africano deixa, com isso, bastante claro que a violência nunca foi a primeira opção dos negros, mesmo na situação colonial, e que, caso fossem obrigados a considerar essa opção, tinham também consciência de que estavam agindo de maneira ambígua em relação à cultura de seus ancestrais. A cultura tradicional, altamente mítica e espiritual, não se identifica com a cultura da violência como revanche.

Com o plano do Régulo, Sila queria quem sabe impedir de chafurdar a cultura africana na lama imperialista do ocidente, de modo a querer preservar o equilíbrio entre o mundo material e espiritual próprios da diversidade cultural africana. Mas, como vimos, o fluxo da História foi outro: além de o ocidente inva- 
dir e dominar territórios, ele sequestrou das culturas locais o equilíbrio secular que as sustentava, obrigando-as a reagirem e a incorporarem a violência como arma de contenção ao controle imperial absoluto. Daí por diante, vemos então um processo de hibridismo compulsório sem precedentes, onde a medida agora é a desmedida, onde a identidade cultural do bissauguineense está cindida, ocupando um entrelugar do imaginário, local de disputas acirradas no desejo de se consolidar uma nova imagem de si mesmo ou da nação. Com o plano do Régulo, a consciência crítica de Sila chega à clarividência: esse revide, embora não consumado, vai continuar a pairar na imaginação do escritor, assumindo, mais adiante (nas suas obras posteriores) contornos utópicos e maravilhosos.

Em Eterna paixão (1994), a esperança como revide encontra a sua expressão concreta. Num país africano governado por uma elite pós-colonial, que abandona o compromisso antes assumido no tempo das lutas independentistas, substituindo o poder colonial por um poder local, mas igualmente opressor, desigual e ditatorial, a possibilidade de um reencontro da comunidade com a ordem política estabelecida é novamente posta em questão. Se antes eram os brancos os opressores, agora são os próprios negros saídos desumanizados pela guerra colonial, desencadeando disputas fratricidas pelo poder. Este poder, que passa tanto pela esfera militar quanto pelo Estado civil, será marcado pela instabilidade, por traições e séries de golpes. Nesse período, veremos uma elite pós-colonial ambígua culturalmente, pois, na mesma medida em que ela retoma o discurso independentista a seu favor, ela também se vê como uma classe social dividida, que sabota politicamente a continuidade do processo de descolonização em face de seus próprios interesses, e ainda se identifica, mimeticamente, com padrões elevados de vida da cultura ocidental.

Nesse contexto, a esperança renasce na trama ficcional de Abdulai Sila. Através de Daniel, um personagem emblemático do romance, Sila propõe uma volta ao "equilíbrio", onde a seiva das tradições africanas e a oportunidade oferecida pelo momento pós-colonial favorecem todos os cidadãos da nação. Daniel, antes banido do governo central, recupera, agora, a esperança numa comunidade tradicional, ao executar uma série de projetos sociais para, depois, retornar ao governo. No governo, Daniel obtém apoio para estender todo o projeto à nação. Nesse romance, um projeto de nação é possível, a esperança se realiza, e passa então a correr em paralelo com o tempo da História presente, ou seja, ao tempo histórico que Sila tanto critica e combate. 
A intervenção compulsória dos brancos em África gerou na vida dos negros africanos um desregramento cultural sem precedentes, chegando a desequilíbrios psicológicos graves (Fanon, 2008). Se a presença colonial branca foi demasiado opressiva, o que fez com que a cultura local fosse sistematicamente abalada pelos imperativos não só econômicos, como também de ordem cultural e religiosa, a guerra de libertação, mesmo tendo sido vitoriosa, foi também um dos elementos de pressão que ajudou a fraturar ainda mais o espírito do negro africano de maneira tão intensa, tão dolorosa e tão impiedosa que nos impede de avaliar a situação de forma total e segura. Mistida (1997), de Abdulai Sila, traduz com vivacidade o momento imediatamente posterior à luta de independência, em especial de Guiné-Bissau. Na sua obra, vagueiam seres absolutamente desorientados, que vivem num território, dão-nos a impressão de que não mantêm vínculo ou familiaridade com a tradição (entendemos "tradição" ou "ancestralidade", no percurso desse texto, como práticas e imaginações culturais seculares das comunidades). Seres que apelam à violência, ao místico ou ao abandono de si mesmos para ver se escapam da nova realidade que os circunda.

Em linhas gerais, Mistida marca, de maneira indelével, a ruptura entre a tradição e a nova ordem estabelecida. As histórias que compõem o livro trazem personagens absolutamente "confusos", cuja percepção parece estar desajustada em relação ao tempo presente e à vida imaterial, espiritual. São seres castigados pela inexorabilidade do Tempo, ou seja, da História compulsória na qual foram arrastados, e, em função disso, afastados da aura protetora espiritual que antes os confortava. Nesse ambiente de miséria humana, Sila busca uma fissura no Tempo para que a verdade cósmica, a ancestralidade, possa libertar-se. Nas histórias apresentadas no livro, metáforas como "bola de fogo" ou "casamento do Sol com a Noite", bem como outras formas de figuração da ideia de redenção, dão o tom da narrativa.

No livro, os vivos estão mortificados, ou seja, alguns personagens vivem atormentados pela falta grave que cometeram enquanto outros estão à espera de uma viragem na História. Em outros termos, há uma divisão psicológica nítida entre eles: existem aqueles que são os atores da nova ordem, e aqueles que, embora tenham sido tragados pelo contexto existente, esperam ver o dia de um novo despertar. Chamam a atenção personagens representativos do segundo grupo pela pureza de espírito e esperança em relação ao futuro. Do primeiro grupo, chamam a atenção personagens movidos pela violência de suas atitudes 
e sentimento de culpa que os acompanha. Nesses últimos, os mortos gritam nos seus ouvidos para que reparem o sofrimento que causaram. Com toda essa simbologia do livro, acreditamos que Mistida é, de alguma forma, uma súplica, uma grande esperança, à reconciliação entre a vida pós-colonial e a ancestralidade (tradição ou nação). Novamente o revide surge no discurso ficcional de Sila, num tempo definido pelo o próprio autor como "kambansa", ou seja, transição.

De acordo com Hall (2011: 41), as identidades formadas no contexto colonial foram construídas na intenção de barrar ou rejeitar o engajamento das histórias locais ou de seus desdobramentos culturais. E um dos locais em que mais se faz sentir essa disputa está justamente no discurso sobre a tradição. As diversas significações (versões) da tradição são postas à margem para que uma única versão sobre a tradição prevaleça, imposta, é claro, pela política dominante. Desse modo, outras matrizes de significados da tradição passam a viver na obscuridade: "A tradição é um elemento vital da cultura, mas ela tem pouco a ver com a mera persistência das velhas formas. Está muito mais relacionada às formas de associação e articulação dos elementos". (Hall, 2011: 243).

Assim, compreendemos a complexidade dos usos e significados da tradição ou ancestralidade no contexto discursivo. O que mais nos importa não é o conteúdo de uma dada tradição, mas como esse conteúdo é expresso e por quem o expressa. O discurso sobre a tradição marca evidentemente uma zona de contato e de disputas entre os vários sistemas de referência culturais e ideológicos. Essa "zona de contato" é, para nós, um espaço absolutamente híbrido, que continuamente "traduz" (Bhabha, 2010) a tradição de acordo com a perspectiva de cada sistema de representação em evidência. Para Bhabha, a "tradução" obriga esses sistemas a rever seus próprios estatutos e a negociar suas diferenças diante outros sistemas com os quais mantém algum tipo de contato. Daí, temos um "local" que se configura pela incomensurabilidade (Hall, 2011: 72), onde há acordos e desacordos contínuos, tendo sempre o desejo da hegemonia do discurso sobre a tradição (ou nação) como troféu.

Com Mistida, o mundo da ancestralidade africana se torna difuso, mais distante, e o horizonte técnico-social do ocidente, com todas as contradições, passa a fazer parte da rotina dos indivíduos. Desse modo, arriscamos a dizer que, com esse livro - uma Odisseia anti-heroica da pós-colonialidade - há um desprendimento mais acentuado da tradição (da proteção dos deuses) e, com a mesma intensidade, uma espécie de subjetivação do indivíduo que ultrapassa as fron- 
teiras étnicas do país. De forma mais enfática e categórica, podemos dizer que, ao cabo da luta independentista, Guiné-Bissau surge como uma só civilização, e não mais um mosaico de etnias agrupadas e administradas por uma civilização de fora. Mas, como toda civilização, surge simbolicamente a partir de um ato de agressão e, posteriormente, de um profundo sentimento de culpa. Essa foi, simbolicamente, a condição de Amambarka. Esse personagem, imagem da nova nação, foi aquele que matou seus próprios pais para instituir um novo poder, uma nova ordem social. E ele, apesar de condenado pelo autor, é, entretanto, o real pivô da história da pós-colonização africana, o divisor de águas entre o passado e o recente presente histórico.

Não por acaso, Amambarka aparece novamente em "As orações de Mansata" (2007). Com isso, Sila parece desejar genericamente fixar a imagem do político e administrador das nações africanas como um representante do "mal" na sociedade pós-colonial em África. Amambarka não é aquele personagem ruim por sua natureza, mas pelo processo histórico que o fez. A sua busca pelo poder, bem como a maneira como ele próprio traduz o medo em ser traído, mostra para nós sua condição compósita ou mestiça por imposição. Ele entende que a garantia de poder pode ser dada pela aura protetora da tradição/ancestralidade, mas, por outro lado, sabe que a sua condição não permite mais acessibilidade a essa mesma tradição. A violência que o fez e reproduz não o permite mais tal vínculo. E o ocidente, que antes prometera proteção a ele, agora hesita ou mesmo começa a deixar claro para o personagem que a sua presença como líder africano já não é mais conveniente aos seus interesses.

Diante desse quadro, Amambarka reconhece sua diferença em relação ao ocidente, desejando, como político e administrador, mais autonomia política para fazer uma série de reformas no país. Essas reformas, além de beneficiar a população, reduziriam a dependência política de Amambarka frente ao ocidente. Se ele conseguir, pela astúcia e violência, recuperar os poderes da tradição, poderá então ser um líder reconhecido pela nação:

Preciso desses poderes [as orações de Mansada, uma espécie de sabedoria ancestral dada por uma sacerdotisa], não para o benefício pessoal, mas para fazer progredir a Nação. Com esses poderes, não vamos pedir esmola a nenhuma outra nação ou instituição estrangeira, vamos ser autossuficientes, respeitados em todo o mundo, ter tudo o que precisamos. (...) Vamos ter escolas para as crianças, 
universidades em todo o país, para todos os jovens, rapazes e meninas, estudarem e serem grandes Homens (sic), cientistas de valor, com conhecimentos profundos da ciência e da tecnologia que vão fazer inveja aos brancos! (Sila, 2007: 99).

Porém, Amambarka termina absolutamente isolado na sua missão. Ao fim e ao cabo, ele não consegue recuperar a proteção espiritual que o reconheceria como sujeito eleito pela comunidade para defender os interesses de todo o povo. Além disso, o personagem não está mais apoiado pelo ocidente, o que o faz suspeitar cada vez mais dos interesses ocidentais.

Assim, a figuração do "mal" é representada por Amambarka: o personagem não é mau porque nasceu mau, porque tem uma natureza interior ruim, mas porque as condicionantes históricas fizeram com que pessoas como ele, um africano da própria terra, se afastassem da própria tradição diante do processo violento de descolonização, e que, em seguida, tendo naturalizado essa violência em si, a perpetuou de maneira trágica. Esse comportamento manifesto pela violência passou, em seguida, a ser identificado como uma prática africana pelo ocidente, e o próprio ocidente entendeu, então, que podia reconquistar seus territórios perdidos em África a partir de um conluio com líderes africanos que tivessem em si essa identificação. Tática, por sua vez, contraditória do ocidente, o que confirma seu padrão duplo no continente africano representado pela literatura de Sila.

Em outras palavras, Amambarka é a figura conturbada, fraturada, da identidade do negro africano pós-colonial, contemporâneo. Ele, na vida pública, é legião. Ele é o negro mestiço no sentido pejorativo: vítima da colonização e opressor dos pós-colonizados. Por isso, Sila, em toda sua ficção, toma-o como sujeito africano a ser combatido, a ser desvendado para ser superado. É preciso, pois, enfrentar esse fantasma do passado que repercute no presente. Sila entende que a viragem para um mundo descolonial está, por certo, no processo de desidentificação do negro africano com esse personagem. Mas, para se chegar à superação dessa condição psicossocial, é preciso, segundo indicações do próprio escritor, retornar à ancestralidade africana. Contudo, como veremos mais adiante, a imagem dessa ancestralidade não é mais hoje a mesma do passado, embora ainda guarde a sua principal mensagem.

Enfim, a permanência da imagem de Amambarka favorece o assédio do (neo) colonizador. Através dele, o negro africano contemporâneo é apresentado ao 
mundo ocidental como sujeito desumano e bestial. Isso reforça a imagem construída sobre o negro no período da colonização e serve, no presente, como argumento legitimador da condição subalterna dos negros africanos no mundo e de intervenções estrangeiras de ordem político-militares compulsórias. Toda a África, a partir dessa perspectiva, será vista como habitada por "não-pessoas" pessoas de existências negadas pelo Direito Internacional (Chomsky, 2012) - , e que, por isso, necessita do "apoio" civilizatório do ocidente.

A figuração de Amambarka, contraditória e potencialmente destrutiva, irá marcar presença em Dois tiros e uma gargalhada (2013), a mais recente publicação de Sila. Nessa peça, Amambarka reforça as características do personagem por nós já percebidas nos livros anteriores do autor. Mesmo guardando independência em relação às obras anteriores - Mistida e As orações de Mansata-, a peça traz novamente toda a problemática anterior do personagem, fazendo, ainda, outras conexões com outros mundos da ficção do autor. Amambarka, nessa peça, quer agora eliminar todos os vetores que obstaculizam a sua ascensão e permanência no poder. Uma dessas forças é, sobretudo, a própria sabedoria local, representada por chefes comunitários conhecidos como Homens-grandes. A peça termina, surpreendentemente, com o fracasso de Amambarka.

Diante do exposto, ou seja, da breve recensão que fizemos da literatura de Sila, arriscamos afirmar que, pelo menos, três grandes questões se apresentam no conjunto da obra ficcional do autor africano. A saber: (1) a tradição cultural africana, (2) a angústia da ruptura com essa tradição e (3) a reinvenção da cultura da tradição africana como um modo híbrido de se relacionar com os novos desafios que a paisagem do(no) mundo contemporâneo impõe. Com os olhos postos no último trabalho literário de Sila, iremos abordar, adiante, os tópicos acima, ainda que ligeiramente.

\section{1- "Vestígios" da tradição cultural africana: comunidade e ancestralidade como valor espiritual, estético, ético e político}

As condicionantes históricas impõem uma condução da História de modo irreversível. Contudo, essas condicionantes são construídas, dialeticamente, através do sujeito. Amambarka e seus comparsas têm suas identidades marcadas a partir da luta de libertação nacional. O grupo confessa que, naquele período, 
havia certa "alegria" em matar, pois identificavam suas vítimas como "traidores", "reacionários" ou "lacaios do colonialismo". Agora, no tempo pós-colonial mais tardio, esse grupo está deslocado, sem apoio popular e também sem os apoios externos que recebia. Contudo, a conduta moral do grupo continua a mesma, e isso faz com que haja um desencantamento com a realidade e uma incompreensão acerca dos movimentos políticos e sociais, vindos de setores que, desde o tempo da colonização, eram vistos com desconfiança e motivo de atritos constantes com os colonizadores. Trata-se de líderes comunitários, antes designados Régulos pelos portugueses, hoje mais conhecidos no país como Homens-grandes.

Se o grupo de Amambarka, com seus matadores e seguidores, obteve êxitos em suas conquistas no passado, foi (nós confiamos nessa hipótese) porque o projeto político africano nacional foi negado aos próprios africanos. Os colonos mostraram sua desumanidade para salvar o direito de ter domínio político sobre a terra, sobre a sua nação. Mas, passado esse período, chega-se a hora de se desarmar, de banir os próprios fantasmas e buscar uma reconciliação com a História. De outro modo, a peça de Sila aponta para um tempo de mudança, um tempo de reconciliação da História com a tradição, de fazer chegar ao topo da organização política da nação a sabedoria e a experiência comunitárias, ou seja, todo o aparato cultural, espiritual, político, técnico e ético que a tradição pode oferecer. Com efeito, esse conjunto de saberes poderá remodelar ou reequilibrar a ordem política em favor de uma imagem favorável de uma nação africana de fato livre, onde a sua humanidade está presente e visível.

A hesitação dos comparsas de Amambarka para matar um chefe comunitário suscita questionamentos relevantes sobre o entrecruzamento da política com a tradição/ancestralidade. Mesmo conscientes do papel a exercer, como justiceiros a mando de Amambarka, eles temem a ancestralidade, pois sabem estar a cometer uma falta grave com o mundo espiritual que ainda os identifica.

Em outros termos, não importando muito o motivo, matar um "mestiço" ("destribalizado") ou mesmo um "branco" não traria para suas próprias vidas nenhum tipo de maldição, nenhum agoiro ou outro mal que pudessem temer. Porém, "eliminar" um Homem-grande é, por certo, negar toda a aprendizagem cultural acerca da vida e do mundo. É exatamente nesse momento em que notamos haver nesses sujeitos africanos uma cisão clara entre a prática social e a norma cultural. Com isso, a política da violência, algo temporal e objetivo, sofre 
um revés, e o poder da ancestralidade, atemporal e subjetivo, ganha força. A cena, enfim, faz com que se recupere "o vestígio" - la trace (Glissant, 1996) negado da tradição, em que a tônica dos eventos, inclusive dos interesses mais imediatos, devem estar subordinados à ancestralidade, e não de outro modo:

Nas sociedades (pós)coloniais, a constituição de novas identidades se deu através do rechaço de antigas identidades. No entanto, essa nova conjectura não eliminou por completo os resíduos ou traços do passado. Esses traços podem, assim, ser observados nas culturas crioulas ao recuperar e revelar discreta, original e imprevisivelmente uma condição identitária até então escondida, secularmente proscrita. (Cardoso, 2014: 135).

O "vestígio" da tradição, sua opacidade, está também no discurso de Amambarka. O personagem pede a seu homem de maior confiança que siga um ritual para matar o Homem-grande: primeiro degolá-lo, depois, dar um tiro em cada um dos olhos. Possivelmente, essa maneira de "eliminar" o velho da comunidade poderia quebrar alguma maldição que poderia cair sobre ele. Isso significa que, apesar de toda a distância em relação à ancestralidade, Amambarka também guardava, através de seus traços, algum vínculo com ela, daí o seu temor. Enfim, Amambarka e seus seguidores sentem que estão em dívida com a ancestralidade, sentem que ela surge como uma voz da consciência (ética), que os acusa dos crimes cometidos e de suas fugas constantes.

\section{2- A mestiçagem compulsória: violência, imitação e poder na representação do mundo africano}

A situação pós-colonial torna o mundo africano num espaço de tensões ideológicas problemáticas cujos agenciamentos exploram as próprias fraturas culturais dos africanos sofridas pelos desenlaces da violência no tempo da colonização e, depois, como reação, nas lutas independentistas. Podemos resumir o cenário da seguinte forma: por um lado, há o constante (e incansável) assédio da burguesia internacional para manter ou reconquistar o domínio político sobre as ex-colônias; por outro lado, há formações ideológicas de bases comunitárias que anseiam resistir às pressões do ocidente. $E$, entre essas duas posições, há a 
burguesia nacional cuja prática política é ambígua tanto em relação à postura do ocidente, quanto às ideologias de base.

Amambarka é, na peça de Sila, um reconhecível representante do poder manifestado pela burguesia nacional. Ele se considera um político progressista imagina o país com o mesmo conforto que existe no ocidente -, mas, por outro lado, é um sujeito profundamente dominado pelo espírito do lucro e do prazer pessoal. Com a representação de Amambarka, Sila mostra a existência de uma burguesia estrangeira que sabe identificar e investir em atores sociais fraturados culturalmente para que eles, posteriormente, trabalhem para ela, para que deem continuidade no seu projeto de conquista, para que executem um projeto ocidental previamente delineado, mesmo que, para isso, signifique gerar mais sofrimentos à população ou sacrifício de vidas humanas.

Se refletirmos um pouco mais sobre a condição de Amambarka, podemos deduzir que na paisagem africana, mesmo com a presença de governantes progressistas (e autoritários, muitas vezes), está em curso um plano cujo saber/ domínio é alienígena. Logo, o pensamento local, africano, é posto à margem. Tal situação denota que a nação africana a que se refere Sila é governada por procuração por uma força estrangeira, e o povo africano dessa nação pouco ou nada contribui na vida política.

Desse modo, à comunidade é negada sua expressão, sendo os seus anseios iludidos ou frustrados toda vez pela burguesia nacional. Amambarka é um exemplo de "mestiçagem cultural" imposta pelo ocidente, que podemos denominar de falsa mestiçagem. O personagem está fora do paradigma da mestiçagem defendido por Édouard Glissant, no qual a "crioulização" (Cardoso, 2014), ideia de mestiçagem defendida pelo intelectual da Martinica, aparece como um modo utópico de ultrapassagem da realidade ou da própria História em face de sua imprevisibilidade nos resultados diante dos diversos sistemas de referências culturais: "[...] la créolisation ne se limite pas à une métissage, dont les synthèses pourraient être prévues". (Glissant, 1997: 194). ("[...] a crioulização não se limita a uma mestiçagem cujas sínteses podem ser previstas").

Com Amambarka não há devir, a nação africana estaria fadada a sempre repetir o mesmo comportamento na cultura.

A indicação clara de que a atitude de Amambarka se replica na esfera social do poder público aparece reforçada no comportamento de Kilin, outro personagem igualmente problemático que aparece na peça. Kilin, espécie de ministro 
do governo, teve infância sofrida. Órfão a partir dos sete anos, teve problemas de autoestima e, na vida adulta, passou a ter um enorme apego ao dinheiro, projetando toda sua imagem pessoal e pública como exemplo de sujeito bem-sucedido a ser reverenciado. Com essa ambição, Kilin orquestra, no governo, um golpe político, recorrendo, inclusive, à violência. Além disso, ele assina secretamente um contrato com uma empresa multinacional, a fim de obter propina. Assim, essa atitude de Kilin, contestada por Sila, reforça a ideia de que figuras da vida pública, desejando alcançar seus próprios interesses, põem em risco os interesses da própria nação, o que faz, portanto, perpetuar a condição de subalternidade do povo africano em relação ao ocidente.

\section{3- "Errância" e o pensamento do poder-saber: a tradição se criouliza sob o signo da "relação"}

A citação de abertura da peça, em língua étnica, constitui numa senha para entendermos melhor a teia discursiva de Abdulai Sila. A tradução do provérbio, oferecida pelo autor (Sila, 2013: 7), diz: "Quem parte para uma viagem sem data de regresso que leve bagagem completa". Para nós, essa citação, além de indicar a atmosfera geral da peça, aponta também para uma razão cultural africana implícita no texto. Grosso modo, trata-se do exercício, na atualidade, de "um pensamento de errância", se se adotarmos a perspectiva de Édouard Glissant (1997: 63):

L'errance, c'est cela même qui nous permet de nous fixer. De quitter ces leçons de choses que nous sommes si enclins à semoncer, d'abdiquer ce ton de sentence où nous compassons nos doutes [...] ou nos déclamations, et de dériver enfin. (A errância é, ela própria, aquilo que nos permite fixar-nos. De deixar as lições das coisas que nós estamos tão inclinados a corrigir, a abdicar desse tom de sentença onde nós confortamos nossas dúvidas [...] ou nossas afirmações, e de derivar enfim).

A errância aponta para uma (co)presença disponível e aberta, num percurso à paisagem do mundo que não responde a nenhum itinerário preconcebido e que, por isso, aponta para uma realização futura permeável à imprevisibilidade. 
Em Sila, a errância é também a própria formulação literária, pois ela realiza a presença poética (e por isso relacional) das coisas, tais como a tradição e a pós-colonialidade, apontando para um horizonte de abertura onde a mestiçagem se faz sentir de maneira inusitada e para além dos impasses entre os vários sistemas de referências culturais. Ainda segundo Glissant (1997), com a errância, o imaginário cultural é deslocado, obrigando o sujeito a sair da prisão, que o prende por um sentimento de unicidade ou de raiz única, para experimentar todas as variações do mundo.

Entretanto, o evento da colonização, bem como os descaminhos dos tempos pós-coloniais, representou um golpe à tradição cultural africana. Em contraposição às identidades existentes, novos formas de identificação cultural passaram a operar no espaço africano, o que fez com que muitos dos africanos começassem a desenvolver cada vez mais um sentimento de apagamento ou de desamparo em relação à própria cultura. Certa desidentificação, em muitos casos compulsória, tornou evidente a fratura da subjetividade do africano, ingressando-o verticalmente num mundo absolutamente híbrido. Ademais, esse novo mundo, híbrido por imposição, aponta para uma situação de não-retorno no domínio da História, onde a tradição (ou ancestralidade), agora maculada, jamais poderá assumir as velhas formas de identificação do passado.

Podemos traduzir esse momento de tensão cultural africano em nós, brasileiros, como a perda da "muiraquitã", a pedra ancestral da identidade cultural brasileira (e também latino-americana), expressa em Macunaíma (1928) de Mário de Andrade [1893-1945], escritor modernista brasileiro. Com essa perda, e daí uma busca constante, temos uma identidade fendida, que se orienta, agora e de forma aberta, para o futuro, na esperança de encontrar aquilo que fora perdido no passado. Assim, é também o roteiro da viagem proposto por Sila. Viajar com toda a bagagem (tradição), mas sem data de retorno, para alhures, ou seja, para num "aqui distante" desembalar e pôr em evidência a ancestralidade reconfigurada. Com isso, Sila alarga o conhecimento sobre a questão da (co) presença das coisas, da possibilidade de "um lá existente" que é o "aqui ainda dormente". Portanto, traduzindo em termos culturais, a viagem não reduz o objeto, pelo contrário, o revela futuramente.

Nesse sentido, imaginamos que, quando estamos diante de uma viagem sem data de retorno, procuramos selecionar e levar tudo aquilo que mais nos poderia fazer falta. Seria preciso, então, analisarmos e decidirmos sobre as coi- 
sas que necessitamos, para que as principais possam caber na mala, e nos desapegarmos sofridamente de muitas outras, ainda que nos possam fazer falta em algum momento. Então, na bagagem de Sila, temos a impressão que ele transporta, de maneira resumida e condensada, toda a tradição cultural africana, na figuração simbólica, talvez, de um único item: o "poder-saber" da tradição local africana.

Com a colonização e, consequentemente com o pós-colonialismo, a vida social africana, em seus múltiplos aspectos (político, religioso, econômico etc), passou a se situar num "campo de forças de poder-saber", aproveitando-nos da citação de Stuart Hall (2011: 111). Todo o aparato da colonização, como instituições de ensino, bancos, hospitais, tecnologias e outros meios criaram uma percepção de que o único sistema de conhecimento e de representação válido era o de matriz ocidental. Desse modo, todo o conhecimento cultural africano e suas estratégias de apoderamento foram recusados na moldura da própria sociedade local africana.

Entretanto, como uma espécie de revide, vemos que na peça de Sila as posições do "saber-poder" do ocidente e da cultura africana se invertem: o "saber-poder" do ocidente é, na primeira parte do livro, contestado, mostrando, através da atitude dos principais personagens, como esse sistema de representação fracassou na sociedade africana. Em contraposição, vemos a afirmação, a partir da segunda parte do livro, do "saber-poder" africano, como prática de orientação ao exercício da política do poder num espaço africano de disputas legítimas. Em outras palavras, Sila traduz a ascensão do "poder-saber" da tradição africana através da articulação e sucesso da comunidade liderada pelos Homens-grandes (Kamala Djonko e Kemeburema), que põem em prática o saber africano (cultural, político, ético e místico) em contraposição aos insucessos da prática da razão ocidental, orientada com exclusividade pela esfera econômica do lucro e do consumo.

O "saber-poder" africano, representado por Sila, não faz, entretanto, tábula rasa do legado (pós)colonial; pelo contrário, aproveita as instituições constituídas para reocupá-las com o seu saber. Nesse momento, temos então o desembalar da bagagem numa data imaginada, onde a força da tradição africana volta a assumir sua posição central no cenário político, através da inserção das comunidades sociais de base negligenciadas, mas profundamente identificadas às mais variadas formas de expressão da cultura africana. Nesse sentido, podemos 
agora compreender melhor a mensagem de Sila posta na fala de um de seus personagens: "Finalmente a nossa terra vai se reconciliar connosco (sic) e as almas dos nossos antepassados podem (sic) descansar em paz". (Sila, 2013: 89). Esse novo tempo, vislumbrado por Sila, é uma reação ao fluxo histórico, ou seja, uma aposta contingencial da História realizada em sua literatura.

Isso posto, a peça de Sila vai além de um teatro pedagógico e de classe, inspirado em Bertold Brecht [1898-1956]. Sila elabora um roteiro, com todo um repertório cultural próprio da África, para dizer aos próprios africanos que é tempo de se curarem das feridas da colonização e de se afastarem dos fantasmas do passado. Com Dois tiros e uma gargalhada, Sila toca na ferida profunda da vivência africana num mundo opressor que se prevaleceu desde o tempo da colonização, mas que agora é chegada a hora de virar a página, e fazer valer os valores da tradição. Essa reconciliação, de que fala Sila, é, na verdade, o reencontro da tradição com a vida política e a tomada, de fato, do poder em África pelos próprios africanos. Ou seja: a expressão do poder deve corresponder aos valores e anseios da comunidade, e não mais aos objetivos de uma mão estrangeira "invisível" ou de uma elite burguesa nacional corrompida.

Enfim, com Sila, após a leitura de sua peça (bem como de suas outras obras), passamos a acreditar que a cultura africana tem muito a nos ensinar: ética, estética e política estão interligadas ao seu discurso, e essa articulação mostra o quanto nós necessitamos de sua literatura. Com Sila, encontramos um convite aberto para o retorno ao absolutamente humano, ou seja, podemos encontrar nele a maior esperança num tempo de uma brutal, hegemônica e universal desesperança.

\section{Considerações finais}

Na leitura que acabamos de propor sobre a literatura de Abdulai Sila, procuramos refletir sobre a consciência e as atitudes dos personagens diante da História - enquanto conceito ocidental - e da tradição, tentando evidenciar que, por mais que os personagens se considerem cônscios de seu papel na narrativa pós-colonial, eles não foram, entretanto, seus verdadeiros autores. Muitos dos indivíduos na pós-colonialidade, sobretudo líderes ou figuras públicas, exerceram o papel contrário ao próprio mundo cultural que os identificava, quando 
aceitaram ser identificados e movidos dentro de um sistema de representação alheio a sua própria cultura. Então, vimos nesse processo uma espécie de repetição (mitificação) do comportamento social e cultural africano, identificado à bestialidade e à violência. Com essa obsedante inscrição nos indivíduos (africanos), confirma-se a narrativa do ocidente através das mentes, da estereotipia e da subalternização contínua do "saber-fazer" africano.

Sila percebe a possibilidade de uma outra narrativa, onde os africanos, além de exercer seu papel histórico, podem também exercer sua autoria na História. Esta não mais apreendida como evento messiânico, mas agora como espaço de resincronização entre mundos de tempos diferentes. Eis, então, a grande questão na ficção de Sila, pois para tornar o contingente da História numa realidade é preciso, antes, desconstruir a imagem psicossocial do negro autóctone elaborada historicamente pelo ocidente para, em seguida, apresentar um novo paradigma, e de validade étnica e política, de organização social.

Entretanto, de acordo com as interrogações de Benjamin (postas como introdução nesse texto), acerca do sujeito e da História, o mover da História não ocorre pari passu com a consciência do indivíduo. Daí a necessidade de o indivíduo compreender a História na medida em que toma consciência dos efeitos e ruinas que ela produz. Na literatura de Sila, vemos claramente como a História produziu seus "efeitos" e "destroços", sobretudo, na vida imaterial dos africanos, ou seja, as identidades e os sistemas de representação autóctones foram dilacerados e seus resíduos foram subordinados ao programa do ocidente e aplicados a seu serviço. Logo, pensar em superar essa condição, dentro e por meio da própria História, é uma flagrante utopia, quando adotamos essa perspectiva benjaminiana. A História, para Benjamin, empurra a humanidade para a catástrofe.

Ora, se não é possível, mesmo que alegoricamente, imaginar uma totalidade do mundo para além da História, pois tudo o que se imagina é resultado da própria imaginação histórica, então, como escapar de seu sufrágio? Pensamos que a resposta está em abandonar o pensamento de totalidade e do sentido da História como algo progressista e linear. Sila, através de sua literatura opera dialeticamente nesses dois eixos: inicialmente mostra a pedagogia da linearidade da História, de como o ocidente tornou a História num conjunto de eventos econômicos e técnicos que universalizaram uma visão de evolução no tempo para todo o mundo, onde culturas afeitas a esse regime foram logo consideradas obstáculos ou vistas como símbolos de atraso. Em decorrência da imposição desse 
regime, veremos na literatura do autor seus efeitos colaterais e como culturas inteiras foram obrigadas a se movimentar teatralmente ao seu redor.

Porém, Sila aponta também para a emergência de um outro eixo de entendimento da História: a História vista agora como algo não linear, que não aponta inexoravelmente à catástrofe e que a totalidade do mundo pode ser pressentida, ainda que não possa ser objetivamente vista. Então, esse novo regime permite a transformação no mundo, onde os sujeitos podem ser os arautos da História, mas nem por isso podem desviar a dinâmica da História a seu próprio interesse. Por quê? Porque o sentido da História é, para Sila, uma rede cíclica que une o material ao imaterial, cujos valores de base são dados pela sabedoria da comunidade. Quando existe harmonia entre os elementos, a História se cumpre, ou seja, reestabelece uma ligação entre a ancestralidade e o tempo presente. Enfim, é sob esse signo maravilhoso da História que Sila quer restabelecer a importância cultural e política africana, e fazer ver aos próprios africanos que é possível pensar uma sociedade, mesmo integrada ao contexto global, sem abandonar por completo suas principais diferenças.

Isso posto, concluímos que a literatura de Sila oferece tanto uma alternativa "crioulizada" de mudança no mundo - pois deseja uma ruptura de paradigmas sem apelar para violência e a partir da imprevisibilidade- , quanto um incentivo aos próprios africanos para que estejam mais conscientes das posições políticas e culturais que necessitam defender. Assim, acreditamos que Dois tiros e uma gargalhada (2013) confirma, como um exemplo estético e sintético mais atual do repertório do autor, a exposição dessas ideias. 


\section{Referências}

BENJAMIN, W. Sobre o conceito de história. In Magia e técnica, arte e política: ensaios sobre literatura e história da cultura. 7 ed. Trad.: Sérgio Paulo Rouanet. São Paulo: Brasiliense, 1994.

BHABHA, H. K. O local da cultura. Belo Horizonte: Editora UFMG, 2010.

CARDOSO, S. II Trilogia pós-colonial da imaginação literária: a prosa africana de Abdulai Sila. In Poéticas da mestiçagem: textos sobre culturas literárias e crítica cultural. Curitiba: Editora CRV, 2014, p. 77-114. Outras versões parciais e avulsas do referido capítulo: CARDOSO, S. Cultura e utopia em Abdulai Sila : uma leitura de Eterna paixão. Polifonia, Cuiabá, MT, v. 20, n. 28, p. 263-278, jul/dez., 2013; CARDOSO, S. História, narração e mestiçagem: uma leitura de $A$ última tragédia. Realis- Revista de Estudos AntiUtilitaristas e PósColoniais, Recife, PE, v. 4, n. 1, 2014, p. 210-219, Jan/Jun., 2014; CARDOSO, S. Em louvor à crioulização: a experiência do abismo em Abdulai Sila. Reflexos- Revue pluridisciplinaire du monde lusophone, Toulouse, FR, v. 2, n. 2, p. 1-12, 2013.

CHOMSKY, N. Um mundo cheio de "não-pessoas". Disponível em: http://www.viomundo.com.br/politica/noam-chomsky-um-mundo-cheio-de-nao-pessoas.html Acesso em: 24 de dez. 2014.

COUTO, Mia. À porta da modernidade, há sete sapatos sujos que necessitamos descalçar. Disponível em : http://www.pordentrodaafrica.com/cultura/mia-couto-a-porta-da-modernidade-ha-sete-sapatos-sujos-que-necessitamos-descalcar Acesso em 24 dez. 2014.

FANON, F. Os condenados da terra. Minas Gerais: Editora UFJF, 2008.

GLISSANT, É. Introduction à une poétique du divers. Paris : Gallimard, 1996.

. Traité du Tout-Monde. Poétique IV. Paris : Gallimard, 1997.

HALL, S. Da diáspora. Identidades e mediações culturais. Organização: Liv Sovik. Trad.: Adelaine La Guardia Resente et al. Belo Horizonte : Editora UFMG, 2011.

SILA, A. A última tragédia. Bissau: Ku Si Mon Editora, 1995. Há uma edição brasileira da obra pela Editora Pallas, Rio de Janeiro, 2006.

. Dois tiros e uma gargalhada. Bissau: Ku Si Mon Editora, 2013.

. Eterna paixão. Bissau: Ku Si Mon Editora, 1994.

. Mistida. Bissau: Ku Si Mon Editora, 1997. O autor publica novamente o livro, sob o mesmo título, juntamente com seus dois romances, numa edição portuguesa: SILA, A. Mistida (Trilogia). Praia- Mindelo: Centro Cultural Português, 2002.

. Orações de Mansata. Bissau: Ku Si Mon Editora, 2007. 